\title{
A Violência Sexual em Nossos Dias: Questões para a Psicanálise
}

Sexual violence in our days: Subjects for psychoanalysis

Soneide de Sales Lima

Pontifícia Universidade Católica do Rio de Janeiro

Vera Pollo

Universidade Estadual do Rio de Janeiro

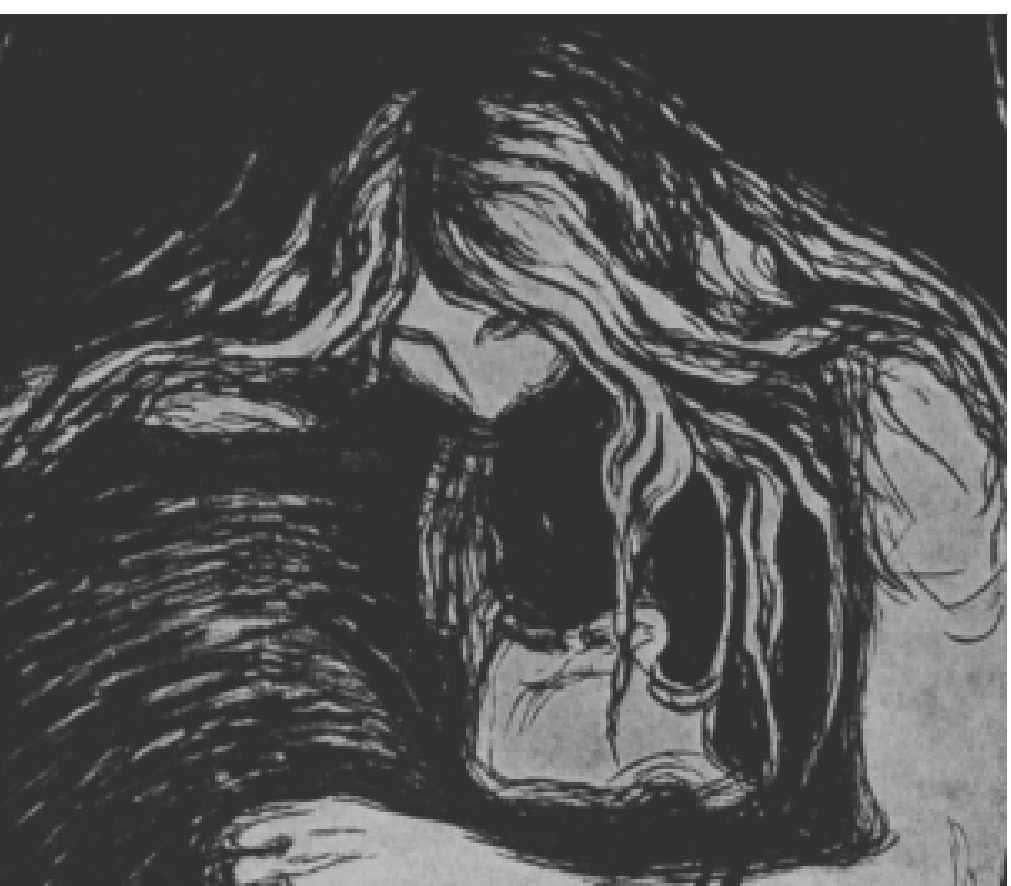




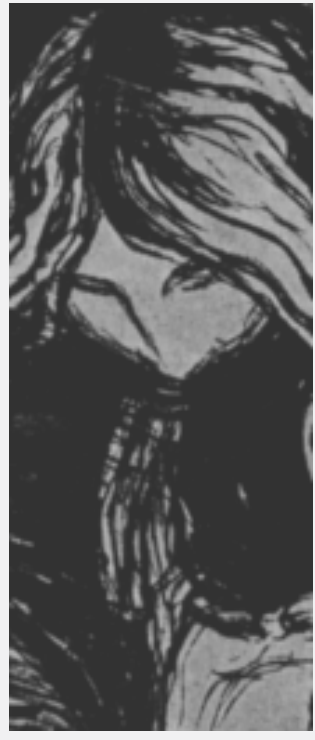

Resumo: O presente texto analisa o tema do abuso sexual buscando trazer, inicialmente, as contribuições teóricas de Freud e de Lacan. Em seguida, são relatados quatro casos clínicos, visando demonstrar a contemporaneidade do tema e explanar alguns impasses clínicos e necessários encaminhamentos.

Palavras-chave: abuso sexual, sedução, fantasia inconsciente, narcisismo, trauma.

Abstract: This text analyses the topic of sexual abuse aimming to bring Freud and Lacan's theoretical contributions to understand it. Four cases studies will be presented in order to demonstrate that this is a contemporary subject and to explain some clinical deadloks and necessary clinical interventions.

Key words: sexual abuse, seduction, unconscious fantasy, narcissism, trauma.

Nossa hipótese é que o crescimento nefasto dos fenômenos de segregação e violência e o formidável desenvolvimento das técnicas de divulgação de informação vêm forçando os psicanalistas a uma espécie de retorno às origens, no sentido de se verem obrigados, não raras vezes, a formular para si próprios a questão que Freud formulou ainda no final do século XIX: houve ou não abuso sexual?

Encontramos diferentes respostas a essa questão ao longo do texto freudiano, mas é a própria realidade psíquica que algumas vezes nos impede de chegar a uma resposta conclusiva em curto espaço de tempo e sem o recurso de um tratamento analítico. Para o sujeito do inconsciente, o desejo pode ter valor de ação; por isso, movido pela culpabilidade inconsciente, ele pode responsabilizar-se pelo ato que apenas desejou. Em casos mais graves, pode até mesmo cometer um primeiro crime como forma de expiar a culpa que o antecede.

Do legado freudiano, e da experiência acumulada no decorrer de seu primeiro século de existência, pode-se deduzir que, para o ser falante, o encontro com o real do sexo é sempre traumático, mas não significa necessariamente um abuso sexual realmente perpetrado. No entanto, foi também o próprio Freud quem nos legou, em 1938, uma advertência última, que traduziríamos nos seguintes termos: as primeiras experiências e impressões sexuais de uma criança deixam marcas definitivas em sua vida, e a perversão é um dos destinos possíveis da pulsão sexual, uma escolha subjetiva.

Crianças continuam sofrendo de abusos e os psicanalistas continuam sendo convocados a se posicionar frente a tais situações. Por isso, no decorrer do presente texto, buscaremos trazer algumas contribuições de Freud e Lacan, assim como relatos de nossa própria experiência, visando não apenas a discutir o tema mas também a ressaltar toda a sua atualidade.

\section{Freud e o abuso sexual}

Em “Estudos sobre Histeria" (1893-95), podese ler, entre outros, o relato do caso da jovem Katharina. Esta revela a Freud que, aos 


\section{Na discussão do caso, Freud assinala, desde então, que se pode comparar as experiências eróticas a ficava sem ar, as coisas ao seu redor ficavam sem expressão, suas pálpebras se fechavam à força e ela ouvia um martelar e um zumbido em sua cabeça. Às vezes, via uma cabeça medonha cujos olhos terríveis a fitavam. Nesses dias, nada conseguia fazer.} momentos traumáticos, porém estabelece uma distinção entre a vivência e a representação. Ressalta, nessa ocasião, que, "embora as representações de cunho sexual não possuam efeitos na vida infantil, as vivências posteriores terão poder traumático quando ligadas às lembranças da infância".

1Por ex:: "auto-análise" para Didier Anzieu; "análise com o não analista Fliess", para Mannoni e J.P. Winter (2001, p.175).

2 Expressão que emprega em 0 Seminário, Livro 11: os quatro conceitos Fundamentais da Psicanálise, cap. quatorze anos, sofrera várias investidas sexuais por parte de um tio, que mantinha também um caso extraconjugal com a empregada. Embora o tempo dos abusos já tivesse passado, continuava sofrendo de sintomas conversivos:

Na discussão do caso, Freud assinala, desde então, que se pode comparar as experiências eróticas a momentos traumáticos, porém estabelece uma distinção entre a vivência e a representação. Ressalta, nessa ocasião, que, "embora as representações de cunho sexual não possuam efeitos na vida infantil, as vivências posteriores terão poder traumático quando ligadas às lembranças da infância". Em nota de rodapé, acrescentada ao caso em 1924, revela que a moça não era a sobrinha, mas a filha do agressor. Chama-nos a atenção a distância de tempo que separa a redação do caso e a nota de rodapé: nada menos do que trinta e um anos! Indício mais do que suficiente, a nosso ver, de sua preocupação com a clínica em geral e com a questão do abuso sexual em particular.

Dizemos com freqüência que, ao escutar as histéricas e fundar a psicanálise, Freud partiu da teoria charcotiana da "lesão funcional" e da hipótese que compartilhou com Breuer acerca do "afeto estrangulado" para chegar à sua primeira teoria das neuroses. É fato. Nesse momento introdutório, considerava que os sintomas histéricos eram diretamente causados por abusos sexuais que os sujeitos haviam sofrido em sua primeira infância, os quais teriam sido perpetrados por adultos ou crianças mais velhas, mais freqüentemente, pelo pai. Porém, já na carta 69 de sua correspondência com Fliess - a "Carta do equinócio" - datada de 21 de setembro de 1897, revela que "não confia mais em sua Neurotica (teoria das neuroses)".
Dentre o grupo de motivos que o levou a dúvidas e indagações, estava a sua surpresa "diante do fato de que, em todos os casos, o pai", sem excluir o seu, "teria de ser apontado como pervertido" (Freud,1897/ 1977, p.351). Não apenas a perversão paterna, mas também a exigível freqüência dessa estrutura clínica lhe parecia suspeita, já que "a perversão teria de ser incomensuravelmente mais freqüente que a histeria, de vez que a doença somente aparece onde houve acumulação de eventos e onde incide um fator que enfraquece a defesa"(ibid, p.351).

Dando continuidade à pesquisa e interpretação dos fenômenos inconscientes relatados por seus pacientes bem como à investigação do seu próprio inconsciente - "auto-análise", na opinião de alguns, "análise com o não analista Fliess", na opinião de outros ${ }^{1}$ - Freud cedo descobriu que o assim chamado "complexo de Édipo", cuja vivência encontra regularmente o ápice nas crianças entre os três e cinco anos de idade, gera fantasias e impulsos com características marcadamente sexuais e/ou agressivas. Esses impulsos e fantasias, como bem sabemos, tomam preferencialmente como objeto os adultos que desempenham as funções materna e paterna.

Tal constatação, que nos parece banal nos dias de hoje e que muitos consideram ultrapassada, representou uma verdadeira ruptura na compreensão da sexualidade humana, primeiramente, ao demonstrar a criança como um sujeito ativo do desejo, não necessariamente um ser passivo diante dos adultos; em segundo lugar, ao revelar que o afeto e a inteligência, longe de seguirem cursos separados, apresentam uma forte dependência mútua, de modo que se pode dizer que a sexualidade humana, na maioria dos casos, é não só infantil, como também intelectual, pois a função da causa, do sentido sexual e traumático do inconsciente, observaria Lacan em 1964, passa inevitavelmente pela "rede dos significantes" ${ }^{2}$. 
O reconhecimento do lugar central que a fantasia ocupa na neurose, cujo valor de verdade reside no fato de ser "plena de desejo", foi um passo de grande alcance na construção da teoria e da prática analíticas. Seguiu-se-lhe a descoberta de que a pulsão sempre se satisfaz. Embora nunca encontre a satisfação completa, em cujo caso se extinguiria, encontra sempre os meios necessários à obtenção de uma satisfação subsidiária, de menor intensidade e, freqüentemente, deslocada. Por exemplo, uma determinada satisfação escópica pode suprir um impulso originalmente oral. "Devora-se com os olhos", diz a sabedoria popular. Além disso, a pulsão possui um caráter reversível, de modo que se passa quase imperceptivelmente da posição ativa à passiva e vice-versa: de comer a ser comido, de cagar a ser cagado, etc.

O ser falante não é um animal provido de instintos periódicos ou cíclicos, mas assujeitado à constância da pulsão. Em 1915², Freud localizou a "prova [da existência] da pulsão" na própria ineficácia da ação motora para interromper sua pressão constante. Ao subdividi-la em quatro elementos - pressão ou força, finalidade, objeto e fonte - observou também que o objeto da pulsão, ou seja, aquilo por meio do qual ela consegue atingir sua finalidade de satisfação, é o que há de mais variável, podendo ser tanto uma parte do próprio corpo do sujeito quanto um semelhante humano, um objeto qualquer do mundo ou da fantasia.

Mais adiante, ao debruçar-se sobre a delicada questão da sexualidade feminina, Freud se viu conduzido, já no início dos anos 1930, a readmitir a existência de "uma nova fantasia de sedução". Esta, no entanto, se Ihe apresentava com duas grandes diferenças em relação à fantasia de sedução pelo pai, não só porque "o sedutor era regularmente a mãe" como também porque tocava "o chão da realidade".
Nesse momento, voltou a observar que os sintomas histéricos derivam de fantasias, entre elas a do sujeito ter sido seduzido pelo pai, mas salientou que a fantasia de sedução materna, que encontrara com regularidade na "história pré-edipiana das meninas", originavase em um evento que realmente tivera lugar. Ao cuidar da higiene corporal da criança, a mãe "inevitavelmente estimulou e, talvez, até mesmo despertou, pela primeira vez, sensações prazerosas nos genitais da menina" (Freud 1933/1976, p.149).

A bem da verdade, já havia dito algo muito próximo em 1905, ao ressaltar que:

"a afeição dos pais pelo filho pode despertar prematuramente sua pulsão sexual (...) a tal ponto que a excitação mental rompe caminho de maneira inequívoca até o aparelho genital" (Freud, 1905/1977, p.232).

A novidade é que Freud vê agora, de forma nítida, o laço que une a fantasia de sedução materna com os impulsos passivos da fase fálica das meninas, isto é, com o desejo de que suas mães as toquem e induzam nelas sensações genitais. Por isso, considera que o fato de tomar o pai como objeto de desejo é, nas meninas, um processo secundário, uma autêntica transferência. O pai "herda" as fantasias e os impulsos que a filha desenvolvera previamente em relação à mãe; ingressa, poderíamos dizer, em uma realidade já constituída.

Impõe-se-nos aqui a retomada de uma observação feita por Lacan em $1967^{4}$. Ele salienta a existência de dois termos diferentes na língua alemã: Realität e Wirklichkeit, e acrescenta :

" (...) não é à toa que Freud se serve do termo Realität quando se trata da realidade psíquica (...) o psíquico não constitui, de modo algum, uma regra para se operar de maneira eficaz na realidade, inclusive no que ele é, na medida em que faz parte dela (...) Não é feito de "a afeição dos pais pelo filho pode despertar prematuramente sua pulsão sexual (...) a tal ponto que a excitação mental rompe caminho de maneira inequívoca até o aparelho genital"

Freud
3 Cf. seu texto Trieb und Tr i e b s ch i c k s a le, equivocadamente traduzido pela Imago por "Os Instintos e suas Vicissitudes", atualmente traduzido por A Pulsão e seus Destinos ”.

4 Cf. sua conferência " $\mathrm{Da}$ psicanálise em suas relações com a realidade", no Instituto Francês de Milão, 18 de dezembro de 1967. 
acordo com uma realidade que é dura, com a qual só existe relação quando se tromba com ela: uma realidade da qual o sólido é a melhor metáfora" (Lacan 1967/ 2003, p.353).

Para Freud, a construção da fantasia é resultado de uma operação em que a libido muda de localização e o objeto, de natureza. Em seus termos, a libido, que iniciara o caminho de volta do objeto externo em direção ao eu, acaba por ficar retida no meio do caminho, investindo em um objeto imaginário. A fantasia inconsciente é o nome freudiano desse espaço entre-dois, nem dentro, nem fora; não se encontra no espaço do eu capaz de assomar à consciência, mas tampouco no não-eu, se assim quisermos nomear o mundo exterior.

Não estamos de acordo com Volnovich (2002), que, ao escrever "Sexualidad Infantil: Usos e Abusos del Poder do Adulto", considera que Freud recua de sua primeira teoria da sedução para não ser levado a questionar "a decência de sua própria família e a integridade do pai" e a não desafiar "o poder médico, do qual esperava aceitação e reconhecimento". Em termos bastante injuriosos, decide qualificar, melhor dizendo, interpretar de forma arbitrária a carta 69 de Freud a Fliess como uma "carta da desculpabilização do pai, que apaga qualquer suspeita de pedofilia familiar", e, como se isso não bastasse, afirma que o abandono da primeira teoria da sedução abriu caminho para tornar invisível o abuso sexual realmente cometido e inocentar seus praticantes.

5 Em (1940[1938]) "Esboço de Psicanálise". Obras Completas, v.XXIII, p.215.

6 Que se leia, entre outros textos de Freud, o ensaio intitulado "A psicologia do escolar".

7 Porém não se deve esquecer toda a ênfase com que Freud afirmará posteriormente não a unidade do eu, mas, ao contrário, sua fragmentação e cisão.

Ora, basta lembrar que, no momento derradeiro de sua obra, como de sua vida, Freud $(1938)^{5}$ reafirma os perigos inerentes ao abuso sexual de crianças por adultos, à sua sedução por crianças ligeiramente mais velhas e mesmo à sua excitação ao ver ou ouvir o ato sexual dos pais, para salientar o quanto essas experiências decidem a vida sexual futura de cada sujeito: da inibição neurótica da sexualidade às mais diversas perversões. Tratase, em sua analogia, de experiências que abrem ou fecham "certos canais dos quais depois [os sujeitos] não poderão se safar".

Nesse ínterim, um terceiro tema, além da função e lugar da fantasia e das moções pulsionais, virá conectar-se, na teoria psicanalítica, às questões do abuso sexual. Estreitamente relacionado ao processo de constituição do eu, Freud o introduz durante a passagem da primeira para a segunda tópica: o narcisismo estrutural e sua relação com a castração. A criança se desliga da autoridade dos pais por meio de um processo ultradoloroso, em que seu eu-ideal - imagem narcísica - é abalado pelo abandono de alguns ideais-do-eu familiares e sua substituição por ideais sociais mais amplamente compartilhados. Aquilo que chamamos, com Lacan, de "ideal materno" é apenas um duplo engrandecido do sujeito", e deixa ver a importância da função mediadora do pai, que Freud não cessou de acentuar.

Voltaremos a esse ponto adiante, mas antes queremos lembrar, com Freud ${ }^{6}$, que os professores são indubitavelmente os primeiros a serem capturados nas séries psíquicas préformadas: fantasias, impulsos e desejos, novamente transferidos. Ninguém mais desconhece a importância da assim chamada 'relação mestre-aluno', quer seja na construção de novos ideais que conduzem os sujeitos à vida ou à morte, quer seja na maior ou menor severidade com que o supereu se põe a medir, em cada um, a distância que separa seu 'eu real' do 'ideal'.

\section{"Ou eu ou ele" - a tensão erótico-agressiva}

Em 1914, Freud postula que uma unidade comparável ao eu ${ }^{7}$ não está constituída desde o início, mas resulta de um processo gradativo em que se deve renunciar ao narcisismo característico da primeira infância. O 
desenvolvimento do eu é, então, o resultado de um esforço para recuperar a satisfação narcísica perdida.

Como operam os narcisismos ditos por Freud primário e secundário? O narcisismo primário da criança está, segundo ele, na dependência direta do narcisismo dos pais, isto é, no fato de que o filho possa ocupar, para estes, o lugar de um ideal, razão pela qual será investido de libido. Nos belos termos freudianos, trata-se do renascer do narcisismo metamorfoseado em amor de objeto, observação à qual acrescenta a ressalva de que, nem mesmo nesse caso, o narcisismo esconde sua verdadeira natureza. Qual é, então, a natureza do amor que os pais dedicam aos filhos? Ora, este não é senão o amor pela própria imagem. Somente o narcisismo dito secundário implica a separação entre libido do eu e libido de objeto, pois corresponde à satisfação passível de ser obtida com "um ideal do eu imposto de fora". Ainda em suas palavras, "tornar a ser seu próprio ideal, como na infância, no que diz respeito às tendências sexuais não menos do que às outras - isso é o que as pessoas se esforçam por atingir como sendo sua felicidade" (Freud, 1914/1987, p. 107).

No projeto que fazem os pais do futuro da criança, "a doença, a morte, a renúncia ao prazer, restrições a sua vontade própria não a atingirão; as leis da natureza e da sociedade serão ab-rogadas em seu favor; ela será mais uma vez, realmente, o centro e o âmago da criação" (Freud, 1914/ 1987, p.98).

Verifica-se, assim, o modo como o "complexo de castração" se torna o principal distúrbio do narcisismo primário na medida em que, ao anunciar a falta, anuncia também a mortalidade do eu, sua transitoriedade. Ao voltar ao tema da castração, em textos posteriores ${ }^{8}$, Freud deixa claro que a angústia de morte é, de fato, uma modalidade da angústia de castração. Além disso, salienta que o eu carrega consigo um duplo de si mesmo, que muda completamente de figura após a castração e o recalque: de símbolo de imortalidade para anunciador da morte.

Por esse motivo, Lacan foi levado a enfatizar inúmeras vezes que o eu não só não é o sujeito como traz em seu bojo uma relação duplamente mortífera, correntemente expressa na interlocução: "Ou eu ou ele!" Há, portanto, uma exclusão implícita no momento mesmo de fundação do eu. Doravante, toda relação dual será regida por uma instabilidade basilar, já que

(...) o outro está sempre prestes a retomar seu lugar em relação a ele, que nele há um eu que sempre é em parte estranho a ele, senhor implantado nele acima do conjunto de suas tendências, de seus comportamentos, de seus instintos, de suas pulsões (Lacan, 1948/ 1998. p. 111).

Para demonstrar experimentalmente a existência dos dois narcisismos, Lacan propôs o estudo do esquema óptico realizado pelo físico Bouasse: o experimento do buquê invertido.

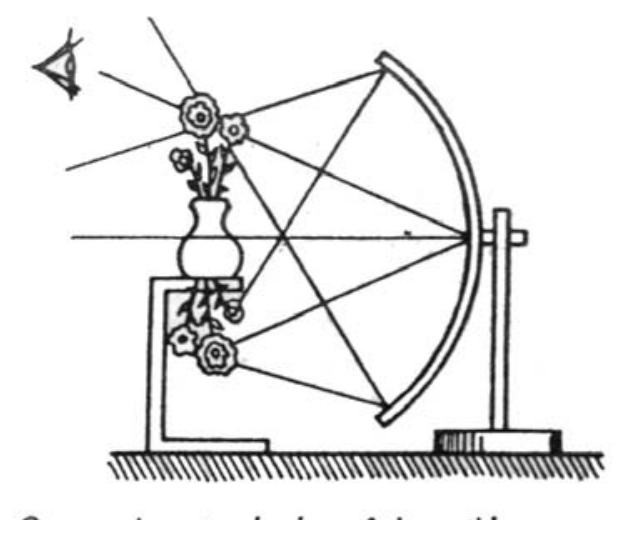

No primeiro esquema óptico, qual seja, o esquema do espelho côncavo (vide figura1, acima), temos uma imagem real que não é exatamente uma imagem completa, mas uma imagem montada (Lacan 1953-4, 1986, p. 94). Nesse esquema, em que o buquê é localizado
8 Que se leia, entre outros, seus textos "O estranho", de 1919 e "Inibição, sintoma e angústia" de 1925. 
embaixo da mesa e o vaso em cima, o espelho côncavo refletirá sempre a imagem real, porém deformada e invertida - trata-se do narcisismo primário - ao passo que, com o acréscimo do espelho plano (cf. Lacan 1953/ 54, 1986, p. 147 - figura 2, abaixo), obter-seá uma imagem unificada. $\mathrm{O}$ espelho plano que Lacan introduz no experimento reflete a imagem virtual e confere ao objeto uma Gestalt, uma imagem inteira, acabada ou ideal, desde que o sujeito esteja no ponto perfeito para encontrá-la. Ela corresponde ao narcisismo secundário.

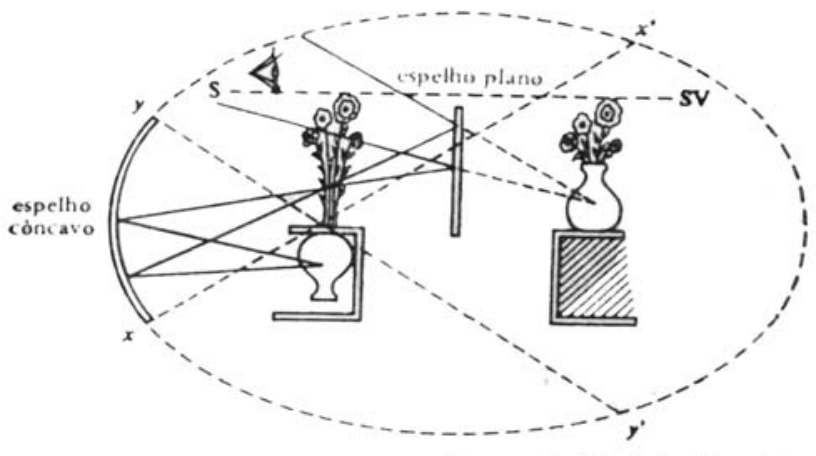

É bem o que nos indicara Freud, enunciando que o eu, secundariamente um "precipitado de investimentos objetais abandonados", é também "a projeção de uma superfície". A experiência do espelho traz, para o filhote do homem, a estruturação fundamental da vida de fantasia com a tensão erótico-agressiva ou, se preferirmos, as projeções de amor e ódio que lhe são correlatas.

Se o outro do espelho não sanciona simbolicamente ${ }^{9}$ a existência da imagem unificada, isto é, se não funciona como Outro da linguagem, a experiência toda se desfaz. A esse buraco no espelho narcísico, de onde nenhuma imagem vem em socorro do sujeito, responde nele o delírio. Em contrapartida, a criança que se reconhece no espelho manifesta claramente expressões de júbilo, mas a jubilação é o encobrimento da falta, pois não é possível imagem alguma daquilo que falta. É o encontro com a castração que o mundo da fantasia, qual um engodo, trata de recobrir.

Todo objeto de amor deverá ser submetido à relação com o Outro, coordenadas simbólicas do sujeito. É inclusive condição de sua existência, Pois, se "a relação objetal deve submeter-se ao quadro narcísico e se inscrever nele" (cf. Lacan, 1953/1986, p. 202), a relação de amor transcende o quadro narcísico, já que Ihe é impossível realizar-se exclusivamente no plano imaginário. Em outros termos, um certo pacto - simbólico, como todo pacto - deverá ser feito na comunidade humana para que a libido se realize, ou seja, venha atenuar as forças de agressão e destruição oriundas da pulsão de morte. O amor só é função do sagrado na mesma medida em que o é do profano, tal como nos indica a raiz etimológica de sacer, que significa simultaneamente o sagrado e o profano.

\section{A interpretação traumática}

Geiza é uma jovem mulher que se lembrava de duas cenas. Presenciara a primeira aos três anos de idade e descreveu-a nos seguintes termos: um homem, patrão de seu pai, chamava a ela e à irmã para virem ao escritório, onde lhes exibia o pênis. Pedia-Ihes, ao mesmo tempo, que o deixassem ver "seus sexos". Já a segunda cena dizia respeito a um episódio ocorrido cinco anos depois, ou seja, quando contava oito anos. Nesta, era beijada por um ancião que morava ao lado de sua casa e que Ihe havia fabricado "um sapatinho" a pedido do pai.

Por várias vezes, mencionou o fato de que soubera por suas primas e irmã que o tio abusava sexualmente delas. Além disso, falou com muita emoção do horror que sentiu na segunda cena e do pavor que sentiu em pensar que o pai poderia matar o autor da agressão, por isso, pelo menos é o que alega, não lhe contou o ocorrido. Tornou-se 
introspectiva e triste, casou-se tarde e tinha dificuldades de obter prazer na vida sexual. Durante as sessões, dizia algumas vezes a seguinte frase: "Meu pai, tal qual meu tio, prefere minha irmã a mim. Meu pai nada quer de mim". Comentou várias vezes que o seu "complexo de inferioridade", como o denominava, tinha como causa o fato de o tio "não ter tido olhos" para ela.

Geiza tem uma estrutura neurótica, tipo clínico histérico, o que indica a existência do recalque e da castração. Seus sintomas retornavam ao simbólico através das dificuldades em manter relacionamentos amorosos e de trabalho, metáforas de seus impasses na assunção do sexo biológico. Estava sempre se queixando da falta de amor, numa reivindicação constante em que se dizia "vítima dos outros".

Queremos chamar a atenção para o fato de que a jovem se deu conta retrospectivamente da curiosidade que sentiu aos três anos e de como ia para bem perto do personagem masculino da primeira cena. É de extrema importância essa revelação, pois o fato de a criança estar vivendo o auge do complexo de Édipo pode levar os pais a algumas confusões acerca da sexualidade dos filhos. Alguns passam a suspeitar de tendências à perversão na vida adulta, ao homossexualismo e a tantas outras. A criança não está necessariamente seduzindo o adulto para chegar ao ato genital, mas interessada em construir teorias sexuais - as chamadas "teorias sexuais infantis" - que dêem conta de sua perplexidade e seu desconforto face à diferença sexual.

Geiza nos lembra a paciente Emma, de Freud $^{10}$, cujo caso se desdobra também em duas cenas, com um intervalo de quatro anos entre elas. A jovem desenvolve a fobia de entrar em lojas sozinha, alega estar correndo o risco de um "abuso sexual" e acredita, inicialmente, que o medo se deve à recordação da cena em que, aos doze anos, entrara em uma loja de roupas e percebera um riso sarcástico nos vendedores. Nessa ocasião, ela saíra correndo, tomada de uma espécie de susto $^{11} \mathrm{e}$, conforme confessaria a Freud, ao mesmo tempo em que achara que os dois vendedores riam de suas roupas, sentiu uma atração sexual por um deles.

Freud não se deu por satisfeito com a explicação da jovem, que Ihe pareceu incongruente, e deu prosseguimento a suas investigações. Sua fobia resolver-se-á, então, a partir da recordação de uma outra cena, quando contava oito anos. Trata-se novamente de entrar em uma loja, não de roupas, mas de doces. Nesta, o dono da confeitaria apertara com a mão os seus órgãos genitais por cima do seu vestido e rira. A jovem se lembra de que, apesar de tudo isso, voltou sozinha ao local. Confessa, por fim, o sentimento de culpa ligado à interpretação subjetiva que a torturava: se voltara sozinha, era porque devia ter gostado e o fizera para provocar o homem.

Esclarece-se, desse modo, que o prazer sexual experimentado, mas não simbolizado na ocasião da primeira cena, reaparece na segunda sob a forma de susto, e as lembranças do riso e da roupa estabelecem a ponte verbal que as une. Sua sensação de estar vestida de forma inadequada na segunda cena torna-se, assim, compreensível, de modo que Freud pôde asseverar, desde então, que "a lembrança fica recalcada apenas quando se torna trauma por ação retardada" (Freud, 1895/ 1950-1977, p. 468), e que o sintoma fundamental dos histéricos é o nojo, sensação que experimentam na ocasião em que poderiam sentir uma excitação sexual. O sintoma é, neles, uma autêntica substituição metafórica.

Embora tenha sido vítima de uma ato de violência sexual, Lúcia é um outro exemplo do efeito traumático da interpretação da lembrança. Aos 12 anos, chega ao ambulatório do N.E.S.A ${ }^{12}$ acompanhada pela mãe, cujas enormes olheiras pretas denunciam, de
É de extrema importância essa revelação, pois o fato de a criança estar vivendo o auge do complexo de Édipo pode levar os pais a algumas confusões acerca da sexualidade dos filhos.
10 Freud se refere a esse caso em seu Projeto para uma Psicologia Científica (1895), pp.464-468.

11 Os grifos nas palavras "sozinha" $e$ "susto" são do próprio Freud.

12 Núcleo de Estudos da Saúde do Adolescente do Hospital Universitário Pedro Ernesto/ UERJ. 
"(...) a devastação que constitui, na mulher, em sua maioria, a relação com a mãe, de quem, como mulher, ela realmente parece esperar mais substância que do pai - o que não combina com ele ser segundo, nessa devastação"

Lacan

13 Instituto Médico Legal.

14 Cf. a distinção estabelecida por Freud, em 1934-1938, em "Moisés e o Monoteísmo", obras Completas, vol. XXIII, p. 95. imediato, seu estado depressivo. Relata imediatamente o estupro sofrido pela filha, há um mês, durante um assalto a mão armada em sua casa. Os assaltantes eram dois homens bastante jovens, que amarraram com cordas a mãe e o filho, dois anos mais novo que Lúcia. O pai estava ausente por motivo de trabalho. Enquanto um dos rapazes vigiava a mãe e o filho, o outro despia e estuprava a filha na frente destes.

Lúcia e sua mãe já haviam comparecido ao $\mathrm{IML}^{13}$ e à delegacia, onde retornariam ainda algumas vezes até a prisão e o reconhecimento de um dos assaltantes. Nesse ínterim, a adolescente fora encaminhada ao nosso serviço, para atendimento médico e psicológico. Como de praxe nesses casos, a ginecologista solicitou exame de gravidez pois a menina já havia tido a menarca - e exames para vírus HIV. Estes últimos deveriam ser repetidos, de seis em seis meses, por um período de dois anos.

Depois de iniciado esse périplo, que bem podemos qualificar de "infernal", encontramonos com Lúcia. Surpreendeu-nos a forma como ela se sentiu prontamente disposta a falar, porém somente após um ano de sessões analíticas semanais iria referir-se diretamente ao episódio do estupro. Ao longo de todo o primeiro ano de atendimento, Lúcia falava sobretudo dos ciúmes que sentia do irmão, que considerava o preferido pela mãe. Mencionava insistentemente a diferença de tratamento que a mãe lhe conferia e ao irmão: para ela, só críticas negativas; para ele, só elogios. Ocasionalmente, descrevia os desentendimentos entre a mãe e o pai, e freqüentemente dava mostras de amor e admiração pelo último. Eventualmente, falava de algum problema na escola onde era uma aluna mediana, embora nunca tivesse repetido o ano. Em suma, a adolescente elaborava a relação mãe-filha, cujo caráter potencialmente devastador não passou despercebido a Freud. Do mesmo modo, podemos ler, em Lacan, seu alerta para
“(...) a devastação que constitui, na mulher, em sua maioria, a relação com a mãe, de quem, como mulher, ela realmente parece esperar mais substância que do pai - o que não combina com ele ser segundo, nessa devastação" (Lacan, 1973/ 2003, p.465).

Exatamente na noite da véspera em que o estupro completaria um ano, Lúcia teve um sonho que nos relatou no dia seguinte. Sonhara com a repetição da cena, ou seja, produzira um "sonho traumático" semelhante aos que ocorrem nas assim chamadas "neuroses de guerra", revelando um esforço de elaboração do trauma prosseguido em nível inconsciente, isto é, desconhecido pelo eu. Contudo, as únicas associações que fez do sonho diziam respeito ao sentimento insuportável de que a mãe a considerava culpada pelo ocorrido, interpretando nesses termos algumas das falas da mãe, como a de que " suas roupas são indecentes e provocativas".

Havia indícios de que necessitava construir um Outro gozador, sobre o qual projetar seus próprios sentimentos de culpa, ligados ao gozo sexual proibido, porém experimentado, malgrado a violência de que fora realmente vítima. Daí em diante, suas notas escolares sofreram uma queda e ela produziu uma série de pequenos sintomas somáticos: rinites, cefaléias e dermatites. Concluímos que o trauma que vivera serviu como desencadeador de uma estrutura e tipo clínicos, certamente prévios, mas, infelizmente, não temos como saber se terá ou não instaurado uma "compulsão à repetição" de futuros maus encontros. A interrupção de seu tratamento, depois do prazo de dois anos, deixou-nos com a pergunta impossível de ser respondida: aonde a conduzirão seus esforços de elaboração?, pois, caso venham a manifestar-se como "efeitos positivos do trauma" ${ }^{14}$ - em contraposição aos "efeitos negativos" em que se constituem os sintomas e inibições, tentativas de esquecer o trauma corresponderão a tentativas de repetir a mesma situação com outras pessoas. 


\section{O encontro com o real do sexo}

A seguir, explanaremos dois casos que chegaram a uma instituição para vítimas de violências domésticas ${ }^{15}$, entre elas, o abuso sexual. Jade, menina de três anos, trazida à consulta pela mãe após encaminhamento do Ministério Público. Esta informa que a suspeita foi levantada pela escola, embora tenha sido ela própria quem tenha chamado a atenção da professora, dizendo-lhe que "deveria estar acontecendo alguma coisa na casa da avó paterna". A pedagoga decidiu "conversar com a menina", e foi novamente a mãe quem nos relatou que, depois da conversa, a criança teria feito o seguinte comentário: "Eu tenho um segredo. Se eu contar, Ruan [um tio de dezessete anos] mata o vovô".

A avó materna nos trouxe a informação de que Jade havia deitado em cima de uma boneca, "como em uma relação sexual". Alegou também mudanças no seu comportamento, do tipo de regressões: "voltou a usar chupeta, a fazer xixi na roupa e a andar relaxada". Além disso, começou a apresentar reações de medo, como o de ficar sozinha na sala ao anoitecer.

Em contrapartida, a avó paterna considerava que as mudanças de comportamento da criança seriam decorrentes das proibições da mãe, que passara a não deixá-la visitar a família do pai. Impossibilitado de pagar a pensão, este último relatou que era proibido de ver a filha e de levá-la em sua companhia nos fins de semana, fato este confirmado pela mãe de Jade.

Nos relatos da mãe e da avó materna, há elementos que a literatura especializada em abuso sexual classifica de "indicadores comportamentais das vítimas de abuso sexual":

- A menina sobe em cima da boneca e faz movimentos que simulam uma relação sexual.
Existe uma regressão claramente observável na conduta da criança: volta a usar chupeta, perde o controle dos esfíncteres, apresenta reações de medo, e outras.

Os medos relatados pela mãe e pela avó materna puderam ser observados também pela psicanalista durante as entrevistas com a criança. Contudo, não se lhes pode atribuir uma explicação unívoca. O primeiro deles qual seja, a fobia ao escuro - é, como se sabe, um medo típico da infância, a que Freud se refere em seu texto "Inibições, sintomas e angústia" (1925) como um argumento contrário à idéia de Otto Rank, segundo a qual a primeira angústia corresponderia ao trauma do nascimento.

Além da fobia ao escuro, Jade parecia temer freqüentemente que a mãe fosse embora , mas era impossível não perceber que se tratava de um medo partilhado também pela mãe, cuja dificuldade em deixar as filhas entrarem na sala "sozinhas", isto é, sem a sua companhia, era visível ao menos arguto dos observadores. É necessário salientar que existe o medo por identificação da criança com o adulto, ou mesmo da criança com outra criança.

Jade referiu-se, durante as entrevistas, à existência de "um segredo" entre ela e a mãe [portanto, o pai estava excluído] e deu-nos a entender que não revelaria seu saber. Em atitude levemente desafiadora, dizia saber os nomes das cores em inglês, mas não iria contálos. Ao juntar as massinhas, voltou a empregar o termo "segredo". Foi interrogada primeiramente pela psicóloga, logo em seguida, pela mãe. À primeira respondeu com o silêncio, e à mãe, disse: "fiz um brinquedo segredo". Estaria ela buscando satisfazer a demanda materna?

De acordo com o "Estatuto da Criança e do Adolescente", a pedagoga deveria ter pedido
15 Núcleo de Atenção à Criança e ao Adolescente. da FIA. É importante salientar que o trabalho realizado nessa instituição tem, entre suas funções primordiais, a investigação. 
à mãe que notificasse sua suspeita ao Conselho Tutelar ou ela mesma deveria tê-lo feito. Além disso, parece-nos pertinente indagar se a formação oferecida em um curso superior de Educação qualifica seus alunos para "conversas com crianças" acerca da vida sexual destas últimas.

Contrariamente às avós, as professoras, com quem Jade passava a maior parte de seus dias, afirmaram nunca ter observado qualquer mudança no comportamento da criança. Por ser um caso cheio de contradições, a equipe não conseguiu chegar a uma conclusão. Por um lado, o discurso da avó materna coincidia com os assim chamados "indicadores comportamentais"; por outro, desconhecer o despertar sexual de uma criança e interpretála exclusivamente através da observação de comportamento, sem dar-lhe voz, seria retroceder à época pré-analítica. Porém, dar voz a uma criança não é o mesmo que induzila a aquiescer com o que lhe dizem os adultos. Jade, em nenhum momento, repetiu à analista a frase que, segundo a mãe, teria dito logo após a conversa com a pedagoga.

A existência de angústia na infância, como nos ensina Freud, não é sequer elemento suficiente para o diagnóstico de neurose. Ela atesta apenas que houve a cisão do eu no encontro com a castração da mãe. Não nos foi possível chegar nem mesmo a uma conclusão diagnóstica, pois esta dependeria da identificação do mecanismo defensivo em jogo: recalque da castração na neurose, desmentido na perversão e foraclusão na psicose. Concluímos tão somente que Jade vivia um momento de intensa angústia, e o lugar de objeto de disputa fálica, que essa criança parecia ocupar entre a mãe e o pai, justificava a indicação de um tratamento analítico.

Passemos ao caso seguinte. Luna é uma adolescente que compareceu à instituição por encaminhamento do DEAM ${ }^{16}$, acompanhada de uma irmã mais velha. Foi recebida pela assistente social por volta das dez horas. Aberto o prontuário, a assistente lhes disse que receberiam comunicação de retorno e que poderiam ir embora, ao que Luna se negou terminantemente. Quando chegamos para o plantão, às quatorze horas, encontrava-se irritada, confusa e ansiosa. Relatou que apanhava muito da mãe, falou sobre sua infância e sobre a agressão sexual que sofrera. Lembrou-se de que o vizinho a tinha levado para a casa dele e de que, na manhã seguinte, acordou "toda suja de sangue na frente e atrás". Dizendo-se cansada de "falar, falar e falar...sempre em vão", a adolescente contou que havia tomado "um suco" oferecido pelo vizinho e que depois ficara "meio zonza". Disse que o homem que a possuíra sexualmente era Deus, mas que ouvia a voz do irmão ausente a cada vez que ele falava. Acrescentou que não queria ter feito sexo, que disse isso a sua família, mas que "ninguém acreditou nela".

Solicitamos que a levassem a um serviço de psiquiatria para que fosse avaliada a necessidade de uma medicação pela presença de idéias delirantes e alucinações auditivas e por seu estado de agitação motora. Não foi o que se passou. A jovem foi abrigada em uma instituição e, após três dias, a evidência de uma psicose desencadeada fez com que a internassem em um hospital psiquiátrico infantil.

O desencadeamento psicótico, que se caracterizou pelo quadro delirante, costuma ter lugar frente a situações que requerem uma resposta simbólica do sujeito. São paradigmas desse tipo de situações o primeiro ato genital praticado na puberdade ou início da vida adulta, a maternidade e a paternidade, o casamento, a nomeação profissional etc., enfim, situações que requerem o funcionamento do significante da função paterna no interior do registro simbólico. Nos quadros de neurose, aparecerão sintomas que 
correspondem a interpretações simbólicas do sujeito dotadas de uma significação fálica, como as dores de cabeça e as tonturas de Katharina ou os impedimentos no amor e no trabalho, de Geiza.

\section{O trauma sexual}

Podemos dizer que, em sentido amplo, o traumático para o sujeito-criança, no encontro com o sexo, é a proximidade do desejo inconsciente, encontro com o Outro desejante, trauma necessário na exata medida em que "o desejo é uma defesa, proibição de ultrapassar um limite no gozo" (Lacan, 1960/ 1998, p.839).

Diante do encontro com a falta - pois, se o outro deseja, é porque lhe falta algo - o sujeito formula para si próprio a pergunta sobre o que o Outro quer dele: Che vuoi?, "Que quer ele de mim?" Para tal pergunta, não há senão uma resposta: a construção da fantasia, dita, por isso mesmo, "fantasia fundamental". Lacan (1960) comenta, em seu escrito Subversão do sujeito e dialética do desejo, que a primeira resposta de toda criança à pergunta sobre o desejo do Outro costuma ser a hipótese de sua própria morte: "pode ele me perder?"

Na esteira de Freud, Lacan (1973) salientou também que a assim chamada "revolução sexual dos anos mil novecentos e sessenta" só fez testemunhar a "maldição do sexo", a tal ponto que, se não existisse a repressão social de que tanto nos queixamos, seria preciso inventá-la. Em “O Seminário, Livro 11: os quatro Conceitos Fundamentais da Psicanálise", comenta, ainda, que o traumático para todo sujeito é o fato copulatório do significante. Se tal comentário é, à primeira vista, enigmático, sua referência nos parece ser a chamada "cópula lógica" ou "frase existencial", em que o verbo ser não pode ser substituído por "idêntico a", isso porque somente de um lado há um termo singular, enquanto, do outro, há um termo geral. Assim, por exemplo, o enunciado "Pedro é um homem" não pode ser substituído por "Pedro é idêntico a um homem", donde se conclui que a virilidade será sempre problemática, e, mais ainda, a feminilidade.

Em suma, o significante desnaturaliza o sexo biológico e toda assunção subjetiva do sexo próprio permanece necessariamente incompleta. Ao transmitir aos filhos a língua materna, os pais transmitem-lhes também a falta. Parafraseando Freud, enunciamos, com Lacan, que "o genitor traumático produz ingenuamente a neurose ${ }^{\prime 17}$. Isso no melhor dos casos, quando a criança é um objeto do narcisismo dos pais. É melhor que seja assim, tanto para a criança quanto para a sociedade que a fabrica; caso contrário, ela é objeto de gozo e reproduzirá indefinidamente essa situação, expondo-se e sendo exposta à violência e ao abuso, pois

“O perverso é aquele que gostaria de restaurar a continuidade entre a posição da criança que goza ingenuamente e o saber adquirido na vida sexual do adulto, por meio do estabelecimento de uma continuidade entre a sexualidade infantil e a sexualidade adulta, isto é, de uma continuidade entre o gozo e o saber. Eis porque o perverso é freqüentemente um pedófilo. O que lhe interessa é proporcionar àquele que goza na posição da criança, àquele que é um brinquedo erótico de seus pais, um saber sobre esse gozo" (Nominé, 2001, p.41, grifos do autor).

Os casos expostos acima nos fizeram refletir sobre o trabalho que desenvolvemos nas instituições de que fazemos parte e em nossos consultórios. O tratamento analítico oferecido a Geiza e a Lúcia reafirmou, mais uma vez, se necessário fosse, a imbricação do afeto e do
$17 \mathrm{Cf}$. Le savoir du psychanalyste-Entretiens de Saint Anne, lição de 4 de maio de 1972. 
intelecto, evidenciou o caráter traumático das lembranças e dos sonhos, desvios de que o inconsciente se utiliza como forma paradoxal de elaboração. No caso de Jade, constatamos a ineficácia do procedimento de investigação, quando a criança se encontra aprisionada ao lugar de objeto da fantasia materna. Luna, enfim, testemunhou que o encontro com o real do sexo, na impossibilidade do recurso à fantasia, desemboca inevitavelmente no delírio.
Em conjunto, nossa reflexão apontou a existência de um traço da sociedade contemporânea em que o ato de investigar vem de tal modo em primeiro plano que se esquece, muitas vezes, de seu correlato necessário, qual seja, a oferta de um tratamento. A investigação é necessária, mas ela não pode ser um fim em si; caso contrário, nada a diferenciará de um "ideal perverso", que enlaça o saber de um ao gozo do outro. 


\section{Soneide de Sales Lima}

Psicóloga e psicanalista, com Mestrado em Pesquisa e Clínica em Psicanálise pela UERJ, Especialização em Psicologia Clínica e Especialização no Atendimento a Crianças e Adolescentes Vítimas de Violência Doméstica, pela PUC-RJ. É membro do Fórum do Campo Lacaniano-Rio de Janeiro. Rua São José de Calazans, 172 - Posse - Nova Iguaçu - Rio de Janeiro. E-mail: soneidelima@ig.com.br

Vera Pollo

Psicóloga e psicanalista, com Doutorado em Psicologia pela PUC-RJ e DEA pela Universidade de Paris VIII. Analista membro da Escola de Psicanálise dos Fóruns do Campo Lacaniano. Trabalha no Núcleo de Estudos da Saúde do Adolescente do Hospital Universitário Pedro Ernesto- UERJ. É uma das organizadoras do livro Comunidade Analítica de Escola (Marca d'Água Livraria e Editora, 1999) e autora de Mulheres Histéricas (Contra Capa, 2003).

Rua Benjamim Batista, 15 apto101. Jardim Botânico, Rio de Janeiro- RJ. E-mail:v.pollo@terra.com.br

Recebido 26/02/04 Reformulado 10/11/04 Aprovado 13/10/05

FREUD, Sigmund. Extratos dos Documentos Dirigidos a Fliess. In Obras Psicológicas Completas. Edição Standard Brasileira. Rio de Janeiro: Imago Editora, 1972/77, vol. I, 1950 (1892-1899). $\overline{1950(1895)}$

$$
\text { . Projeto para uma Psicologia Científica. In op. cit., vol. I, }
$$

Estudos sobre a Histeria. In op. cit., vol. II, 1893-1895. Vol.VII, 1905.

Três Ensaios sobre a Teoria da Sexualidade. In op. cit 1914.

Sobre o Narcisismo: uma Introdução. In op. cit., vol. XIV

. Os Instintos e suas Vicissitudes. In op. cit., vol. XIV, 1915

. A Perda da Realidade na Neurose e na Psicose. In op. cit., vol.XIX, 1924 $\overline{1926(1925)}$

Inibições, Sintomas e Ansiedade. In op. cit., vol. XX,

. Sexualidade Feminina. In op. cit., vol. XXI, 1931

Feminilidade. In: op. cit., vol. XXII, 1933(1932).

Moisés e o Monoteísmo: três Ensaios. In op. cit., vol. XXIII, 1939(1934-38).

. Esboço de Psicanálise. In op. cit., vol. XXIII, 1940(1938). LACAN, Jacques. O Estádio do Espelho como Formador da Função do Eu. In Escritos. Rio de Janeiro: Jorge Zahar Editor, 1998 (1936).

. O Seminário, Livro 1: os Escritos Técnicos de Freud. Rio de Janeiro: Jorge Zahar Editor, 1986 (1953-1954).
O Seminário, Livro 2: o Eu na Teoria de Freud e na Técnica da Psicanálise. Rio de Janeiro: Jorge Zahar Editor, 1987 (1954-1955).

O Seminário, Livro 3: as Psicoses. Rio de Janeiro: Jorge Zahar Editor, 1988 (1955-1956).

Subversão do Sujeito e Dialética do Desejo. In Escritos. Op. cit., 1960.

O Seminário, Livro 11: os quatro Conceitos Fundamentais da Psicanálise. Rio de Janeiro: Jorge Zahar Editor, 1998 (1964).

Da Psicanálise em suas Relações com a Realidade. In Outros Escritos. Rio de Janeiro: Jorge Zahar Ed., 2003 (1967).

Le Savoir du Psychanalyste. Entretiens de Saint' Anne. Inédito, 1972 (1973).

Televisão. Rio de Janeiro: Jorge Zahar Ed., 1993

NOMINÉ, Bernard. Adolescência ou a Queda do Anjo. In Revista Marraio. Formações Clínicas do Campo Lacaniano no 1. Rio de Janeiro, 2001,pp. 35-44.

VOLNOVICH, Juan Carlos. Sexualidad Infantil: Usos e Abusos del Poder Adulto.In Volnovich, Jorge R. (org.) Abuso Sexual en la Infancia. Buenos Aires/ México: Lumem Humanitas, 2002, pp.101-123.

WINTER, Jean-Pierre. Os Errantes da Carne. Estudos sobre a Histeria Masculina. Rio de Janeiro: Companhia de Freud Editora, 2001. 